\title{
Factors affecting the development of scar formation in abdominal surgery performed for gynecologic and obstetric conditions
} Jinekolojik ve obstetrik nedenli abdominal cerrahilerde skar gelișimini etkileyen faktörler

\section{Serpil Aydoğmuș, Kıymet Handan Kelekçi*, Mustafa Șengül, Emine Demirel, Șemsettin Karaca*, Raziye Desdicioğlu, Sefa Kelekçi}

Izmir Katip Çelebi University Faculty of Medicine, Department of Obstetrics and Gynecology, *Department of Dermatology, Izmir, Turkey

\begin{abstract}
Background and Design: The aim of this study is to investigate whether there can be a difference in types of scars developed on the same type of incisions due to cesarean section or benign gynecologic operations, and to examine the effect of regenerative process occurring in the puerperal period on scar formation.

Materials and Methods: A total of 586 female patients aged 20-40 years, who applied to our dermatology and gynecology and obstetrics outpatient clinics, were included in this case control study. Patients who were operated due to benign gynecologic conditions were assigned to group $1(n=293)$, and those who underwent cesarean section to group $2(n=293)$, and the types of scars were compared. A p value of less than 0.05 was considered statistically significant.

Results: Atrophic and hypertrophic scars were developed in 237 (80.9\%) and 56 (19.1\%) of group 1 patients, respectively. However, 245 (83.6\%) of patients in group 2 had atrophic scars and 48 (16.4\%) had hypertrophic scars. In terms of the type of scar distribution, no significant difference was found between the two groups $(p>0.05)$.

Patients with hypertrophic scar formation constituted $53.8 \%$ of group 1 patients and $46.2 \%$ of group 2 patients. There was no significant difference between the groups for the risk of hypertrophic scar formation ( $p>0.05)$

Conclusion: Our study concluded that there is no significant difference in scar formation on abdominal incision site between benign gynecologic surgeries performed at any period of childbearing age and cesarean section. In addition, the presence of striae, wound infection or hematoma, and duration of wound healing were found to be associated with the risk for hypertrophic scar formation in incision sites in both cesarean section and benign gynecological operations.
\end{abstract}

Keywords: Cosmetic dermatology, puerperium, risk factors, surgical incision

Öz

Amaç: Bu çalışmanın amacı benign jinekolojik operasyonlar veya sezaryen nedeniyle uygulanan aynı tipteki insizyonlarda gelişen skar tiplerinin birbirinden farklı olup olmadığııın araştıııması ve puerperal dönemde oluşan rejeneratif sürecin skar gelişimi üzerine etkisi olup olmadığııın incelenmesidir.

Gereç ve Yöntem: Bu olgu kontrol çalışmasında üniversitemiz Dermatoloji ve Kadın Hastalıkları ve Doğum polikliniklerine başvuran, 20-40 yaş aralığında toplam 586 kadın çalışmaya dahil edildi. Hastalar benign jinekolojik nedenlerle operasyon geçirenler (grup 1) ve sezaryen geçirenler (grup 2) olmaküzereikigruba ayrıldı. Verilerskar tiplerine görekarşılaştıııldı. İstatistiksel anlamlııkiçin 0,05'ten küçük pdeğerlerianlamlıkabuledildi. Bulgular: Benign jinekolojik nedenlerle operasyon geçiren 293 hastanın 237'sinde $(\% 80,9)$ atrofik, 56'sında (\%19,1) hipertrofik tipte skar gelişirken sezaryen operasyonu geçiren 293 hastanın 245'inde (\%83,6) atrofik, 48 (\%16,4) hastada hipertrofik tipte skar geliştiği saptandı. Skar tiplerinin dağılımı açııından gruplar arasında istatistiksel olarak anlamlı fark saptanmadı $(p>0,05)$. Hipertrofik tipte skar gelişen hastaların \%53,8'inin grup 1'de \%46,2'sinin grup 2'de olduğu saptandı. Hipertrofik tipte skar gelişim riski açısından gruplar arasında istatistiksel olarak anlamlı fark saptanmadı ( $p>0,05)$. Sonuç: Çalışmamızda gebelikte uygulanan sezaryen operasyonu ile doğurganlık çağının herhangi bir döneminde uygulanan benign jinekolojik

Address for Correspondence/Yazışma Adresi: Serpil Aydoğmuş MD, İzmir Katip Çelebi University Faculty of Medicine, Department of Obstetrics and Gynecology, Izmir, Turkey Phone: +90 5052429173 E-mail: serpilaydogmus@gmail.com Received/Geliş Tarihi: 09.11.2015 Accepted/Kabul Tarihi: 06.04.2016

CCopyright 2017 by Turkish Society of Dermatology and Venereology

Turkderm-Turkish Archives of Dermatology and Venereology published by Galenos Yayınevi. 
operasyonlar arasında abdominal insizyon yerinde skar oluşumu açısından anlamlı fark olmadığı sonucuna varılmışır. Sezaryen operasyonu ve benign jinekolojik operasyonlar sonrasında insizyon yerinde hipertrofik skar gelişimi açısından daha önceden stria varlığı, yara yerinde enfeksiyon veya hematom gelişmesi, yara iyileşmesi süresinin on günden uzun olması gibi faktörlerin benzer oranda risk oluşturduğu tespit edildi.

Anahtar Kelimeler: Kozmetik dermatoloji, puerperium, risk faktörleri, cerrahi insizyon

\section{Introduction}

Wound healing is one of the most complex biological processes occurring in the human body. Many different biological mediators are activated after trauma in order to form a synchronized response. In adults, wound healing may result in formation of a non- functioning mass of fibrotic tissue, i.e., scar ${ }^{1}$. Wound healing can result in a normal linear scar formation, hypertrophic, atrophic or keloid scars or contractures ${ }^{2}$. Hypertrophic scars represent an abnormal connective tissue response due to trauma, inflammation, burn or surgery in predisposed patients. Pathological scar formation, which is undesirable from a cosmetic viewpoint, adversely affects quality of life in functional and social aspects ${ }^{3}$.

Tension of the wound, presence of infection, density of melanocytes, genetic predisposition, hypoxia, young age, pregnancy and puberty have been defined as risk factors for hypertropic scar formation'. The effects of pregnancy and puerperium on wound healing, scar formation and fibrosis still remain contradictory.

Increased estrogen levels are believed to be associated with hypertrophic scar formation by transforming growth factor (TGF-beta) during pregnancy and puberty ${ }^{3}$. Various studies have demonstrated that increased levels of estrogen in pregnancy affects the synthesis of collagen and other connective tissue components. Relaxin hormone secreted during pregnancy decreases fibrosis by reducing extracellular matrix and collagenase synthesis ${ }^{46}$. During puerperium, a 6 -week period of regeneration process of pregnancy when anatomical and physiological changes disappear, plasma hormone levels return to normal in 2-3 weeks ${ }^{7-9}$. We were unable to identify any studies focusing on physiological changes during puerperium and the effects of regeneration on wound healing in the literature.

Therefore, we aimed to compare the types of scars in patients with the same type of incisions due to benign gynecological conditions and cesarean sections.

\section{Materials and Methods}

This case control study was carried out in İzmir Katip Çelebi University, Atatürk Training and Research Hospital between February 2013 and September 2013. Ethics approval for the study was obtained from Izmir Katip Çelebi University Ethics Committee (No: 2013-90) and it was in agreement with the Declaration of Helsinki for Medical Research involving human subjects. Informed consents were obtained from all patients.

A total of 586 female patients visited dermatology and gynecology and obstetrics outpatient clinics at our hospital with transverse suprapubical incisions due to cesarean sections or benign gynecological conditions performed a minimum of one year ago. Patients younger than 20 and older than 40 years, pregnant or lactating at the time of the study, having by oblique or vertical incisions, having neurological, psychiatric or connective tissue disorders, revised scars, adhesive scars or keloids were excluded from the study.
All patients were examined by an expert dermatologist and we recorded medical histories, skin types and the total length of the scars. Examination findings and medical records of the patients as well as data on age, height, body mass index, skin type, tobacco use, numbers of gravity and parity and surgical procedures, family history of scar formation, presence of infection, striae or secondary sutures, type of suture material used, time of the most recent operation and the removal of the sutures and the opening of the occlusive dressing were noted.

We compared 293 women with benign gynecological conditions (group 1) and a cohort of age-matched women operated on for cesarean sections (group 2) for the types of scars (atrophic or hypertrophic). We used SPSS (version 15.0, 2006; SPSS Inc., Chicago, IL, USA) for statistical analysis. A p value of less than 0.05 with a confidence interval (CI) of $95 \%$ was considered statistically significant. We reported nominal variables as well as demographic variables as counts and percentages in the tables. The variables that had interval or ratio scales were reported as minimums, maximums, means, and standard deviations in the descriptive statistics tables. We tested linear associations between pairs of nominal variables of the interest using a chi-squared test of independence when the dimensions of the cross-tabulations exceeded $2 \times 2$. Once a statistically significant chi-squared measurement was obtained, the proportions of the relevant groups were tested for significant differences using z-tests with Bonferroni-adjusted nominal $p$ values. Additionally, the odds and relative risk ratios were reported for the events of interest where the $2 \times 2$ cross-tabulations were in question.

\section{Results}

The demographic data of the two groups are summarized in Table 1. We found that demographic data and skin types were similar between the two main groups. Considering the 293 patients, who were operated

Table 1. Baseline patient characteristics

\begin{tabular}{|c|c|c|c|}
\hline & Group 1 & Group 2 & $p^{*}$ \\
\hline Age & $34.02 \pm 5.69$ & $30.68 \pm 5.93$ & 0.29 \\
\hline Weight (kg) & $68.35 \pm 11.95$ & $64.63 \pm 10.14$ & 0.19 \\
\hline Height $(\mathrm{cm})$ & $161.4 \pm 6.55$ & $162.25 \pm 5.9$ & 0.25 \\
\hline BMI $\left(\mathrm{kg} / \mathrm{m}^{2}\right)$ & $26.24 \pm 4.55$ & $24.59 \pm 3.89$ & 0.07 \\
\hline Gravity & $2.61 \pm 1.97$ & $2.17 \pm 1.15$ & 0.53 \\
\hline Parity & $2.09 \pm 1.60$ & $1.44 \pm 0.75$ & 0.43 \\
\hline Lenght of scar $(\mathrm{cm})$ & $10.18 \pm 2.36$ & $10.04 \pm 2.51$ & 0.64 \\
\hline Time since operation & $3.89 \pm 2.90$ & $3.99 \pm 2.92$ & 0.70 \\
\hline $\begin{array}{l}\text { Skin type } \\
2 \\
3 \\
4 \\
5 \\
6\end{array}$ & $\begin{array}{l}32(10.9 \%) \\
207(70.6) \\
53(18.1) \\
1(0.3 \%) \\
0\end{array}$ & $\begin{array}{l}9(1.8 \%) \\
357(72.9 \%) \\
116(23.7 \%) \\
7(1.4 \%) \\
1(0.2 \%)\end{array}$ & 0.17 \\
\hline
\end{tabular}


on for benign gynecological conditions, 237 (80.9\%) had atrophic scars and 56 (19.1\%) had hypertrophic scars; atrophic and hypertrophic scar formation was found in 245 (83.6\%) and 48 patients (16.4\%) in the cesarean section group, respectively. No statistically significant difference was observed in terms of hypertrophic scar formation between the two groups ( $>0.05)$ Atrophic scars were detected in $237(49.2 \%)$ of the group 1 patients and 245 (50.8\%) of the group 2 patients; hypertrophic scar formation was observed in 56 patients (53.8\%) in group 1 and 48 patients (46.2\%) in group 2. We did not observe any significant difference between these two groups in terms of the distribution of the types of scar formation ( $p>0.05$ ).

Hypertrophic scar formation was determined in $36.3 \%$ and $11.4 \%$ of group 1 patients with and without striae, respectively. The presence of striae was found to be statistically relevant to the presence of hypertrophic scars in group $1(p<0.01)$ Atrophic and hypertrophic

Table 2. Evaluation of the risk factors of scar formation within group 1

\begin{tabular}{|c|c|c|c|c|}
\hline \multirow{2}{*}{\multicolumn{2}{|c|}{ Independent variable }} & \multicolumn{3}{|c|}{ Group $1(n=293)$} \\
\hline & & \multirow{2}{*}{$\begin{array}{l}\text { Atrofic, } \\
\text { n (\%) } \\
58(63.7)\end{array}$} & \multirow{3}{*}{\begin{tabular}{|l|}
$\begin{array}{l}\text { Hypertrophic, } \\
\text { n (\%) }\end{array}$ \\
$33(36.3)$ \\
$23(114)$ \\
\end{tabular}} & \multirow{3}{*}{\begin{tabular}{|l|}
$p^{*}$ \\
0.001
\end{tabular}} \\
\hline \multirow{2}{*}{$\begin{array}{l}\text { The presence of } \\
\text { striae }\end{array}$} & Yes & & & \\
\hline & No & $179(88.6)$ & & \\
\hline \multirow[t]{2}{*}{ Suture material } & Nonabsorbable & $164(85.9)$ & $27(14.1)$ & \multirow{2}{*}{0.003} \\
\hline & Absorbable & $73(71.6)$ & $29(28.4)$ & \\
\hline \multirow{2}{*}{ Smoking } & Yes & $73(76.8)$ & $22(23.2)$ & \multirow[t]{2}{*}{0.223} \\
\hline & No & $164(82.8)$ & $34(17.2)$ & \\
\hline \multirow{3}{*}{$\begin{array}{l}\text { Occlusive } \\
\text { dressing }\end{array}$} & 11 day & $125(85.6)$ & $21(14.4)$ & \multirow{3}{*}{0.024} \\
\hline & 22 day & 99 (78.6) & $27(21.4)$ & \\
\hline & $33+$ day & $13(61.9)$ & $8(38.1)$ & \\
\hline \multirow{2}{*}{$\begin{array}{l}\text { Wound infection } \\
\text { or hematoma }\end{array}$} & Yes & $8(44.4)$ & $10(55.6)$ & \multirow{2}{*}{0.001} \\
\hline & No & $229(83.3)$ & $46(16.7)$ & \\
\hline \multirow{2}{*}{$\begin{array}{l}\text { Suture removal } \\
\text { time }\end{array}$} & 1-7 day & $127(88.2)$ & $17(11.8)$ & \multirow{2}{*}{0.106} \\
\hline & $8+$ day & $37(78.7)$ & $10(21.3)$ & \\
\hline \multirow{2}{*}{$\begin{array}{l}\text { Secondary } \\
\text { suture }\end{array}$} & Yes & $1(20.0)$ & $4(80.0)$ & \multirow{2}{*}{0.001} \\
\hline & No & $236(81.9)$ & $52(18.1)$ & \\
\hline \multirow{3}{*}{$\begin{array}{l}\text { Wound healing } \\
\text { time }\end{array}$} & $10-10$ day & $214(84.6)$ & $39(15.4)$ & \multirow{3}{*}{0.001} \\
\hline & $211-20$ day & $19(57.6)$ & $14(42.4)$ & \\
\hline & $321+$ day & $2(40.0)$ & $3(60.0)$ & \\
\hline \multirow{2}{*}{$\begin{array}{l}\text { The number of } \\
\text { operations }\end{array}$} & Single & $204(86.1)$ & 33 (13.9) & \multirow{2}{*}{0.001} \\
\hline & Multiple & $33(58.9)$ & $23(41.1)$ & \\
\hline \multirow[b]{2}{*}{ Scar length } & $2-12 \mathrm{~cm}$ & $224(83)$ & $46(17.0)$ & \multirow{2}{*}{0.002} \\
\hline & $12+\mathrm{cm}$ & $13(56.5)$ & $10(43.5)$ & \\
\hline \multirow{3}{*}{ Skin type } & $11-2$ & $2(100)$ & 0 & \multirow{3}{*}{0.426} \\
\hline & $23-4$ & $234(81.0)$ & 55 (19.0) & \\
\hline & $35-6$ & $1(50)$ & $1(50)$ & \\
\hline \multirow{2}{*}{$\begin{array}{l}\text { Family history of } \\
\text { scar formation }\end{array}$} & Yes & $229(83.3)$ & $46(16.7)$ & \multirow[t]{2}{*}{0.234} \\
\hline & No & $39(75.0)$ & $13(25.0)$ & \\
\hline
\end{tabular}

Group 1: Benign gynecologic operations, calculations were based on $\chi 2$ (benign)- $\chi 2$ (C-section) wit, h df(1)-df(2) * $p<0.05$ scars were observed in $85.9 \%$ and $14.1 \%$ of patients sutured with nonabsorbable materials in group 1, respectively. The corresponding rates were $71.6 \%$ and $28.4 \%$, respectively when absorbable suture materials were used. A statistically significant relationship was detected between scar formation and the type of suture material $(p<0.01)$ The use of nonabsorbable suture materials was found to be correlated with an increase in atrophic scars [odds ratio (OR): 2.41 95\% Cl: 1.3354.363] and a decrease in hypertrophic scar formation (OR: $0.41495 \%$ Cl: 0.229-0.749). Hypertrophic scar formation was detected in $14.4 \%$, $21.4 \%$ and $38.1 \%$ of group 1 patients who had received occlusive dressings for one, two, and three days, respectively. As the duration of the occlusive dressing period lengthened, the risk of atrophic scar formation tended to decrease. However, hypertrophic scars were observed more often in these patients $(p<0.05)$. Hypertrophic scars were reported in $55.6 \%$ of cases with wound infection or hematoma; $16.7 \%$ of cases exhibited hypertrophic scars independent of infection or hematoma in group $1(p<0.01)$. The presence of wound infection or hematoma was found to increase the risk of hypertrophic scar formation 6-fold (OR: 6.223 95\% Cl: 2.330-16.616).

Hypertrophic scars were found in $80 \%$ of cases with secondary sutures; atrophic scars were found in $81.9 \%$ of patients without secondary sutures $(p<0.01)$. Secondary sutures increased the risk of hypertrophic scars 18-fold (OR: 18.154 95\% Cl: 1.998-165.780).

A statistically significant relationship was detected between the duration of wound healing and the scar type. Atrophic scars were detected when wound healing persisted for more than 11 days. On the other hand, hypertrophic scars were detected when wound healing lasted less than 11 days at higher rates in group $1(p<0.01)$ In group 1 , hypertrophic scar formation was observed in $13.9 \%$ of patients who underwent a single surgical procedure and in $41.1 \%$ of patients who underwent multiple surgeries $(p<0.01)$. The risk of atrophic scars was 4 times higher in patients who underwent only a single surgery (OR: 4.309 95\% Cl: 2.256-8.229).

Hypertrophic scars developed in $13.9 \%$ and $41.1 \%$ of cases with a scar length shorter and longer than $12 \mathrm{~cm}$, respectively. Longer scars were found to be statistically significantly correlated with hypertrophic scar formation $(p<0.01)$.

In group 1, skin type, tobacco use, family history of abnormal scars and the time until sutures were removed were independent of the type of scar that developed (Table 2).

In group 2, the skin type and the suture materials used, smoking, occlusive dressing, number or operations and secondary sutures were also irrelevant with types of scars (Table 3 ). Atrophic scars occurred in 134 patients $(88.2 \%)$ in group 2 without striae, hypertrophic scars occurred in 18 patients $(11.8 \%)$ in group $2(p<0.05)$. The presence of striae was significantly correlated with hypertrophic scar formation in groups 1 and 2; striae increased the risk of hypertrophic scar formation by 4-fold and 2-fold, respectively (OR: 4.428 95\% Cl: 2.408-8.143 and OR: 2.012 95\% Cl: 1.065-3.801).

Hypertrophic scars were observed in 27 patients (35.5\%) with a family history of hypertrophic scar formation and 21 patients (9.7\%) without a family history. These findings imply that family history increased the risk of developing hypertrophic scars 5-fold (OR: 5.143 95\% Cl: 2.6839.857). In group 2, hypertrophic scars developed in $8.2 \%$ and $31.7 \%$ of cases in whom the sutures were removed within the first 7 days and after 7 days, respectively $(p<0.01)$. Removing sutures within the 
Table 3. Evaluation of the risk factors of scar formation within group 2

\begin{tabular}{|c|c|c|c|c|}
\hline \multirow{2}{*}{\multicolumn{2}{|c|}{ Independent variable }} & \multicolumn{3}{|c|}{ Group $2(n=293)$} \\
\hline & & \multirow{2}{*}{\begin{tabular}{|l|} 
Atrofic, $\mathrm{n}(\%)$ \\
$111(78.7)$ \\
\end{tabular}} & \multirow{3}{*}{\begin{tabular}{|l|} 
Hypertrophic, $\mathbf{n}(\%)$ \\
$30(21.3)$ \\
$18(11.8)$ \\
\end{tabular}} & \multirow{3}{*}{$\begin{array}{l}p^{*} \\
0.029\end{array}$} \\
\hline \multirow{2}{*}{$\begin{array}{l}\text { The presence of } \\
\text { striae }\end{array}$} & Yes & & & \\
\hline & No & $134(88.2)$ & & \\
\hline \multirow{2}{*}{$\begin{array}{l}\text { Family history of } \\
\text { scar formation }\end{array}$} & Yes & $49(64.5)$ & $27(35.5)$ & \multirow{2}{*}{0.001} \\
\hline & No & $196(90.3)$ & $21(9.7)$ & \\
\hline \multirow[b]{2}{*}{$\begin{array}{l}\text { Suture removal } \\
\text { time }\end{array}$} & 1-7 day & 78 (91.8) & $7(8.2)$ & \multirow[b]{2}{*}{0.001} \\
\hline & $8+$ day & $28(68.3)$ & $13(31.7)$ & \\
\hline \multirow{3}{*}{$\begin{array}{l}\text { Wound healing } \\
\text { time }\end{array}$} & 0-10 day & $206(862)$ & 33 (13.8) & \multirow{3}{*}{0.009} \\
\hline & 11-20 day & $34(69.4)$ & $15(30.6)$ & \\
\hline & $21+$ day & $5(100)$ & 0 & \\
\hline \multirow{2}{*}{$\begin{array}{l}\text { Wound infection } \\
\text { or hematoma }\end{array}$} & Yes & $21(60.0)$ & $14(40.0)$ & \multirow{2}{*}{0.001} \\
\hline & No & $224(86.8)$ & $34(13.2)$ & \\
\hline \multirow{3}{*}{ Skin type } & $11-2$ & $6(100)$ & 0 & \multirow{3}{*}{0.361} \\
\hline & $23-4$ & $234(83.0)$ & $48(17)$ & \\
\hline & $35-6$ & $4(100)$ & 0 & \\
\hline \multirow[b]{2}{*}{ Smoking } & Yes & $105(81.4)$ & $24(18.6)$ & \multirow[t]{2}{*}{0.374} \\
\hline & No & $139(85.3)$ & $24(14.7)$ & \\
\hline \multirow[b]{2}{*}{ Suture material } & Nonabsorbable & 127 (87.6) & $18(12.4)$ & \multirow{2}{*}{-0.069} \\
\hline & Absorbable & $118(79.7)$ & $30(20.3)$ & \\
\hline \multirow{3}{*}{$\begin{array}{l}\text { Occlusive } \\
\text { dressing }\end{array}$} & 1 day & 109 (84.5) & $20(15.5)$ & \multirow{3}{*}{0.925} \\
\hline & 2 day & $105(82.7)$ & $22(17.3)$ & \\
\hline & $3+$ day & 31 (83.7) & $6(16.2)$ & \\
\hline \multirow{2}{*}{$\begin{array}{l}\text { The number of } \\
\text { operations }\end{array}$} & Single & $167(82.7)$ & $35(17.3)$ & \multirow{2}{*}{0.515} \\
\hline & Multiple & $78(85.7)$ & $13(14.3)$ & \\
\hline \multirow{2}{*}{ Scar lenght } & $2-12 \mathrm{~cm}$ & $216(83.4)$ & 43 (16.6) & \multirow{2}{*}{0.779} \\
\hline & $12+\mathrm{cm}$ & 29 (85.3) & $5(14.7)$ & \\
\hline \multirow[t]{2}{*}{ Secondary suture } & Yes & $5(62.5)$ & $3(37.5)$ & \multirow{2}{*}{0.102} \\
\hline & No & $240(84.2)$ & 45 (15.8) & \\
\hline
\end{tabular}

Group 2: Cesarean section, calculations were based on $\chi 2$ (benign)- $\chi 2$ (C-section) with $\mathrm{df}(1)$ $\operatorname{df}(2){ }^{*} p<0.05$ first week significantly reduces the risk of hypertrophic scar formation (OR: 0.193 95\% Cl: 0.070-0.533) (Table 4). Hypertrophic and atrophic scars were detected in $13.8 \%$ and $86.2 \%$ of cases in whom wound healing ended up within 10 days, respectively. However, after 10 days, hypertrophic scar formation was observed in $13.8 \%$ of cases and atrophic scar formation was observed in $69.4 \%$ of cases $(p<0.01)$.

\section{Discussion}

There are many contradictory results in the literature about the effects of hormonal, immunological and metabolic changes of pregnancy and puerperium on wound healing. In this study, we found that the type of scar that developed was similar for the same type of incision irrespective of the reason for surgery. Although abnormal scar formation can lead to functional, cosmetic and physiological problems, the physiopathology of such scar formation still remains a mystery ${ }^{6}$. Abnormal scar formation has been attributed to a high skin tension, genetic factors, increases in the extracellular matrix, a long duration of healing, and hormonal factors ${ }^{10-13}$. The most commonly investigated hormonal factor is estrogen, which affects wound healing by regulating the expression of various genes associated with regeneration, matrix production, epidermal function, and inflammation ${ }^{13}$. Many studies showed that hyperestrogenic conditions, such as pregnancy and puberty, increase the risk of hypertrophic scar formation; atrophic scar formation was at the forefront in the postmenopausal period characterized by hypoestrogenism ${ }^{14,15}$

Puerperium is a regeneration process in which pregnancy-related physiological changes disappear. After labor, involution of the reproductive system begins, and pregnancy-induced changes in all organ systems and serum hormones return to pre-pregnancy levels except prolactin ${ }^{9}$. Prolactin is also known to affect skin physiology. Many studies have shown that prolactin can affect angiogenesis, immune modulation and vascular endothelial growth factor expression ${ }^{16}$.

Another important factor involved in wound healing is stem cells, whose popularity has recently increased. With stem cell treatment, accelerated wound healing and reductions in scar formation have been observed by many researchers ${ }^{17,18}$. We compared the scar types in patients operated on for different reasons (but with the same type of incisions)

Table 4. Variance of significant risk factors according to the scar types

\begin{tabular}{|c|c|c|c|c|c|c|c|c|}
\hline & \multicolumn{4}{|l|}{ Group 1} & \multicolumn{4}{|l|}{ Group 2} \\
\hline & \multicolumn{2}{|c|}{ Atrofic scar type } & \multicolumn{2}{|c|}{ Hypertrofic and mixt scar type } & \multicolumn{2}{|c|}{ Atrofic scar type } & \multicolumn{2}{|c|}{ Hypertrofic and mixt scar type } \\
\hline & OR value & $95 \% \mathrm{Cl}$ & OR value & $95 \% \mathrm{Cl}$ & OR value & $95 \% \mathrm{Cl}$ & OR value & $95 \% \mathrm{Cl}$ \\
\hline Suture material & 2.413 & $1.335-4.363$ & 0.414 & $0.229-0.749$ & 1.794 & $0.950-3.388$ & 0.557 & $0.295-1.053$ \\
\hline $\begin{array}{l}\text { Family history } \\
\text { of scar formation }\end{array}$ & 0.652 & $0.321-1.324$ & 1.535 & $0.755-3.119$ & 0.194 & $0.101-0.373$ & 5.143 & 2.683-9.857 \\
\hline $\begin{array}{l}\text { Wound infection or } \\
\text { hematoma }\end{array}$ & 0.161 & $0.060-0.429$ & 6.223 & 2.330-16.616 & 0.228 & $0.106-0.490$ & 4.392 & $2.041-9.452$ \\
\hline Secondary suture & 0.055 & $0.006-0.503$ & 18.154 & $1.988-165.780$ & 0.313 & $0.072-1.354$ & 3.200 & $0.738-13.867$ \\
\hline $\begin{array}{l}\text { Number of } \\
\text { operations }\end{array}$ & 4.309 & $2.256-8.229$ & 0.232 & $0.122-0.443$ & 0.795 & $0.398-1.587$ & 1.257 & $0.630-2.510$ \\
\hline
\end{tabular}


with age-matched patient group with different indications. Our goal was to investigate indirectly how the effects of the regeneration process of the puerperium and hormonal and immunological factors affect wound healing and scar formation. Our inability to record a difference in scar types may be due to our use of indirect evaluation of hormonal and immunological factors by clinical results or the balance between factors that may increase or decrease the risk of hypertrophic scars.

The risk of hypertrophic scarring increases with the presence of striae. There have been no studies in the literature observing the relationship between the presence of striae and scar formation. However, in another study that used the same control group as this study, the researchers showed that hypertrophic scars were associated with the presence of striae. This finding depended on changes in the composition of the skin ${ }^{19}$. Absorbable sutures may also affect wound healing. Long-term cosmetic results were found to be similar when either absorbable suture material or traditional nonabsorbable sutures are used, especially on regions of the body where skin tension is higher ${ }^{20}$. In group 1 patients, the use of nonabsorbable suture material was determined to increase the risk of atrophic type scars 2.4-fold in our study.

In the cesarean section group, the use of nonabsorbable sutures was observed to be related to atrophic scars. However, this relationship was not statistically significant. Removal of the sutures within 7 days was found to reduce the risk of hypertrophic scar formation. Atrophic scars may be related to decreases in immunological impulses. Wound infection negatively affects the inflammatory phase of wound healing because of the effect of bacteria-derived mediators by increasing the production of metalloproteinases and delaying epithelization ${ }^{21,22}$. An increased inflammatory response eventually increases the risk of hypertrophic scar formation ${ }^{23}$.

In our study, we found that wound infection/hematoma increased the risk of hypertrophic scarring 6-fold. A delay in epithelization increases the formation of hypertrophic scars ${ }^{24,25}$. In our study, similar to other studies, we found that epithelization that exceeded 10 days significantly increased the likelihood of hypertrophic scar formation.

Hypertrophic scars are known to commonly form in regions of the body where the skin tension is high ${ }^{26,27}$.

In our study, hypertrophic scars were more prevalent in group 1 patients who received secondary sutures. However, the increase in the risk was not statistically significant in group 2 patients.

Local factors such as the suture material used in gynecological operations, the duration of use of the occlusive dressing, and the length of the scar were determined to increase the risk of hypertrophic scar formation. However, the same effect was not observed in the cesarean section group. This difference is believed to be related to the decrease in inflammatory response due to pregnancy-induced immunosuppression.

\section{Study Limitations}

Strength of our study is that our patients all derived from a homogenous group of the same gender in the same monotype surgical incision. We also included a large cohort, and many data were available from medical records. We also took into account possible risk factors, which have not been studied in the literature before. However, some of the data that were obtained anamnestically may be considered to be the limitations of the study.

\section{Conclusion}

In conclusion, physiological changes during puerperium have no positive or negative effect on hypertrophic scar formation after cesarean section. Additional clinical studies observing the effects of hormonal, metabolic and immunological factors of the puerperium on wound healing and scar formation are necessary.

\section{Acknowledgement}

The group 2 cases of this study were the part of the cohort observed in the study which performed by Kelekçi et al. ${ }^{19}$.

\section{Ethics}

Ethics Committee Approval: The study was approved by the İzmir Katip Çelebi University Local Ethics Committee (No: 2013-90), Informed Consent: Consent form was filled out by all participants.

Peer-review: Externally peer-reviewed.

\section{Authorship Contributions}

Surgical and Medical Practices: Serpil Aydoğmuş, Kıymet Handan Kelekçi, Concept: Serpil Aydoğmuş, Kıymet Handan Kelekçi, Design: Serpil Aydoğmuş, Kıymet Handan Kelekçi, Data Collection or Processing: Mustafa Şengül, Analysis or Interpretation: Serpil Aydoğmuş, Kıymet Handan Kelekçi, Literature Search: Emine Demirel, Şemsettin Karaca, Raziye Desdicioğlu, Sefa Kelekçi, Serpil Aydoğmuş, Kıymet Handan Kelekçi, Writing: Serpil Aydoğmuş.

Conflict of Interest: No conflict of interest was declared by the authors. Financial Disclosure: The authors declared that this study received no financial support.

\section{References}

1. Gurtner GC, Werner S, Barrandon Y, Longaker MT: Wound repair and regeneration. Nature 2008;453:314-21.

2. Seifert O, Mrowietz U: Keloid scarring: bench and bedside. Arch Dermatol Res 2009;301:259-72.

3. English RS, Shenefelt PD: Keloids And Hypertrophic Scars. Dermatol Surg 1999;25:631-8.

4. Sherwood OD: Relaxin's physiological roles and other diverse actions. Endocr Rev 2004;25:205-34

5. Unemori EN, Amento EP: Relaxin modulates synthesis and secretion of procollagenase and collagen by human dermal fibroblasts. J Biol Chem 1990;265:10681-5.

6. Huang X, Arnold G, Lewis M, Guzman L, Grove BH, Unemori EN, Zsebo $\mathrm{K}$ : Effect of relaxin on normal and impaired wound healing in rodents. In: Tregear GW, Ivell R, Bathgate RA, Wade JD, eds. Relaxin 2000. Dordrecht, The Netherlands. Kluwer Academic Publishers;393-7.

7. Martin AG, Leal-Khouri S: Physiologic skin changes associated with pregnancy. Int J Dermatol 1992;31:375-8.

8. Midgley AR Jr, Jaffe RB: Regulation of human gonadotropins. II. Disappearance of human chorionic gonadotropin following delivery. J Clin Endocrinol Metab 1968;28:1712-8.

9. Resnik, R: The Puerperium. In: Maternal Fetal-Medicine, Principles and Practice, Creasy, RK, Resnik, R (Eds), W.B. Saunders, Philadelphia 2004:165.

10. Tziotzios C, Profyris C, Sterling J: Cutaneous scarring: Pathophysiology, molecular mechanisms, and scar reduction therapeutics. Part II. Strategies to reduce scar formation after dermatologic procedures. J Am Acad Dermatol 2012;66:13-24;quiz 25-6.

11. Sherris DA, Larrabee WF Jr, Murakami CS: Management of scar contractures, hypertrophic scars, and keloids. Otolaryngol Clin North Am 1995;28:105768

12. Guo S, Dipietro LA: Factors affecting wound healing. J Dent Res 2010;89:21929

13. Hardman MJ, Aschoft GS: Estrogen, not intrinsic aging, is the major regulator of delayed human wound healing in the elderly. Genome Biol 2008;9:80. 
14. Shu YY, Maibach HI: Estrogen and Skin Therapeutic Options. Am J Clin Dermatol 2011;12:297-311.

15. Ashcroft GS, Mills SJ, Lei K, et al: Estrogen modulates cutaneous wound healing by down regulating macrophage migration inhibitory factor. J Clin Invest 2003;111:1309-18.

16. Foitzik K, Langan EA, Paus R: Langan and Ralf Paus. Prolactin and the Skin: A dermatological perspective on an ancient pleiotropic peptide hormone. $J$ Invest Dermatol 2009;129:1071-87.

17. Lam MT, Nauta A, Meyer NP, et al: Effective delivery of stem cells using an extracellular matrix patch results in increased cell survival and proliferation and reduced scarring in skin wound healing. Tissue Eng Part A 2013;19:73847.

18. Liu S, Zhang $H$, Zhang $X$, et al: Synergistic angiogenesis promoting effects of extracellular matrix scaffolds and adipose-derived stem cells during wound repair. Tissue Eng Part A 2011;17:725-39.

19. Kelekçi $\mathrm{KH}$, Karaca \$s, Demirel $\mathrm{E}$, ve ark: Cerrahi insizyon sonrasi skar oluşumunu etkileyen risk faktörleri. Turkderm 2015;49:213-7.

20. Karounis $H$, Gouin $S$, Eisman $H$, et al: A randomized, controlled trial comparing long-term cosmetic outcomes of traumatic pediatric lacerations repaired with absorbable plain gut versus nonabsorbable nylon sutures Acad Emerg Med 2004;11:730-5.

21. Bowler PG, Duerden BI, Armstrong DG: Wound microbiology and associated approaches to wound management. Clin Microbiol Rev 2001;14:244-69.

22. Lipsky BA, Berendt AR, Cornia PB, et al: Infectious Diseases Society of America clinical practice guideline for the diagnosis and treatment of diabetic foot infections. Clin Infect Dis 2012;54:e132-73.

23. Wang J, Hori K, Ding J, et al: Toll-like receptors expressed by dermal fibroblasts contribute to hypertrophic scarring. J Cell Physiol 2011;226:126573.

24. Darby IA, Hewitson TD: Fibroblast differentiation in wound healing and fibrosis. Int Rev Cytol 2007;257:143-79.

25. Mustoe TA, Cooter RD, Gold MH, et al: International clinical recommendations on scar management. Plast Reconstr Surg 2002;110:560-71.

26. English RS, Shenefelt PD: Keloids and Hypertrophic Scars. Dermatol Surg 1999;25:631-8.

27. Singh N, Perfect JR: Immune Reconstitution Syndrome and Exacerbation of Infections after Pregnancy. Clin Infect Dis 2007;45:1192-9. 